\title{
Seasonal variability of the antimicrobial activity of the essential oil of Lippia alba ${ }^{1}$
}

\author{
Variabilidade sazonal da atividade antimicrobiana do óleo essencial de Lippia alba
}

\author{
Terezinha Feitosa Machado², Rita de Cássia Alves Pereira ${ }^{2 *}$ e Valéria Chaves Vasconcelos Batista ${ }^{3}$
}

\begin{abstract}
Lippia alba is a shrub of the Verbenaceae family, popularly known as lemon balm. It's essential oil is said to have broad-spectrum antimicrobial activity whose effectiveness varies according to its composition, which is influenced by both biotic and abiotic factors. The present study aimed to evaluate the antimicrobial effectiveness of oil taken from the leaves of $L$. alba collected at different times of the year, against microorganisms of importance in food. The oil, obtained by hydrodistillation, was tested against standard cultures of Pseudomonas aeruginosa, Salmonella choleraesuis, Escherichia coli, Staphylococcus aureus, Listeria monocytogenes and Listeria innocua using agar diffusion techniques. The different sampling times had a big influence on the efficiency of the oil, which varied in relation to each microbial species. From December to February the best response was against S. aureus. Against L. monocytogenes, the oil was effective from June to August, while for L. innocua, the oil presented the same response for three periods of the year, differing only from March to May. Correlation of meteorological data for 2010 makes it possible to verify that characteristics typical of the period from December to February in the town of Paraipaba, in the Brazilian state of Ceará (high temperatures, long periods of sunshine and low rainfall) favoured the action of the oil against $S$. aureus. In turn, from June to August, seasonal conditions enhanced the action of the oil against L. monocytogenes and L. innocua.
\end{abstract}

Key words: Lippia alba. Antimicrobial activity. Seasonality.

RESUMO - Lippia alba é um arbusto da família Verbenaceae, popularmente conhecida como erva-cidreira. Seu óleo essencial é citado com amplo espectro de atividade antimicrobiana, cuja eficácia varia em função da sua composição, que sofre influência de fatores bióticos e abióticos. O presente trabalho teve como objetivo, avaliar a eficácia antimicrobiana do óleo de folhas de L. alba, coletadas nas diferentes estações do ano, frente a microrganismos de importância em alimentos. O óleo, obtido por hidrodestilação, foi testado contra culturas padrões de Pseudomona aeruginosa, Salmonella choleraesuis, Escherichia coli, Staphylococcus aureus, Listeria monocytogenes e Listeria innocua, utilizando as técnicas de difusão em ágar. Observou-se uma grande influência das diferentes épocas de coleta na eficiência do óleo, que variou em função de cada espécie microbiana. No período dezembro - fevereiro, a melhor resposta foi frente à $S$. aureus. Para L. monocytogenes a maior eficácia do óleo ocorreu no período junho - agosto, enquanto que para L. innocua o óleo apresentou a mesma resposta em três períodos do ano, diferenciando apenas no período compreendido entre março e maio. A correlação dos dados meteorológicos do ano de 2010 permite aferir, que as características típicas do período dezembro a fevereiro no município de Paraipaba-CE (altas temperaturas, longos períodos de insolação e baixo índice de precipitação pluiométrica) favoreceram a ação do óleo frente $S$. aureus. No período de junho a agosto, por sua vez, as condições da estação potencializaram a ação do óleo contra L. monocytogenes e L. innocua.

Palavras-chave: Lippia alba. Atividade antimicrobiana. Sazonalidade.

\footnotetext{
*Autor para correspondência

${ }^{1}$ Recebido para publicação em 20/04/2012; aprovado em 19/02/2014

Projeto de pesquisa da EMBRAPA (Empresa Brasileira de Pesquisa Agropecuária)

${ }^{2}$ Embrapa Agroindústria Tropical, Fortaleza-CE, Brasil, terezinha.feitosa@embrapa.br, cassia@cnpat.embrapa.br

${ }^{3}$ Departamento de Engenharia de Alimentos, Universidade Federal do Ceará, Fortaleza-CE, Brasil, valeriacvb@ig.com.br
} 


\section{INTRODUCTION}

A wide variety of microbial species is reported to be the causal agent of spoilage and illness transmitted by food, among these Salmonella spp., Listeria monocytogenes, Staphylococcus aureus, Pseudomonas aeruginosa, Escherichia coli, Fusarium spp., Aspergillus spp., Penicillium spp., Rhizopus spp, among others (VIUDA-MARTOS et al., 2007).

Chemical products have been used to control microbial growth and reduce the incidence of toxic infection from food, however synthetic antimicrobials are sometimes associated with adverse effects, such as reactions of allergic hypersensitivity and immune suppression. There has therefore been increasing interest in research into alternative natural antimicrobials that are effective against pathogens in food, and less harmful to human health (GAO et al., 2011).

Essential oils from plants (EOs) have been used as flavouring agents in foods and beverages. Due to their natural origins and the presence of active phytochemicals such asflavonoids, terpenoids and carotenoids among other substances (CORRÊA, 1992; MATOS et al., 1996), they make up one of the most important groups of raw materials for the food, pharmaceutical, perfume and like industries (BAKKALI et al., 2008; MORAIS, 2009; TEPE et al., 2005). Their antimicrobial activity, described in many studies (ADÁMEZ et al., 2012; AGUIAR et al., 2008; KOTZEKIDOU; GIANNAKIDIS; BOULAMATSIS, 2008; NGUEFACKA et al., 2012; SANDRI et al., 2007; SCHELZ; MOLNAR; HOHMANN, 2006; SMITHPALMER; STEWART; FYFE, 2001), may be considered as the additional intrinsic determinant of the quality, safety and shelf life of the food. Moreover, they are classified as having GRAS status (Generally Recognized As Safe), considering the low risk of the development of resistance by pathogenic microorganisms (TATSADJIEU et al., 2009). However, the production of EOs in plants is not stable, nor homogeneously distributed. Many conditions influence their content and composition, such as temperature, luminosity, rain, wind and soil, in addition to such technical factors as the type of crop, cultivation, methods of propagation and post-harvest management (CASTRO, 2001; MORAIS, 2009; SOUZA et al., 2008).

Lippia alba, popularly known as lemon balm, is a plant of the Verbenaceae family, native to South America. The composition of its essential oil presents quantitative and qualitative variations which depend on various factors such as the season, time of flowering, age of the plant, amount of circulating water and geographic and climatic factors (CORRÊA, 1992; MATOS, 1998; TAVARES et al., 2005).
Considering the popular use of Lippia alba in treating many types of diseases, the objective of the present study was to evaluate the antimicrobial activity of the EO from the leaves of this species against microorganisms which are of importance in food, relating the observed results to meteorological data on temperature, total sunlight, relative humidity and accumulated rainfall in the city of Paraipaba, in the Brazilian state of Ceará, the place the plant material was produced and obtained.

\section{MATERIAL AND METHODS}

Samples of the leaves of Lippia alba (MILL.) N.E.Brown (Verbenaceae) were collected from an experiment set up in the experimental area of Embrapa Agroindústria Tropical, located in the town of Paraipaba, Ceará. A subsample of the species was deposited in the herbarium of Embrapa Genetic Resources and Biotechnology [Recursos Genéticos e Biotecnologia] under the number CEN 73,791.

Every three months fresh leaves were collected, which were submitted to hydrodistillation for $4 \mathrm{~h}$, using a Clevengertype apparatus. The EO separated by centrifugation, was dried with $\mathrm{Na}_{2} \mathrm{SO}_{4}$ and its volume measured in a graduated centrifuge tube. The oil obtained was transferred to amber glass bottles with screw caps and stored at $2^{\circ} \mathrm{C}$ until analysis (CRAVEIRO; MATOS; ALENCAR, 1976).

The pathogenic bacterial species, and those causing food-spoilage, which were used in this study were Escherichia coli ATCC 10536, Listeria innocua ATCC 19115, Listeria monocytogenes ATCC 33090, Pseudomonas aeruginosa ATCC 9027, Salmonella choleraesuis ATCC 10708 and Staphylococcus aureus ATCC 6538P. All species were kept at $-80{ }^{\circ} \mathrm{C}$ in a BHI broth containing $10 \%$ glycerol. Working cultures were prepared by a subculture of $100 \mu \mathrm{l}$ from each stock culture, in $9 \mathrm{~mL}$ of brain heart infusion broth (BHI, Merck) and incubated at $35{ }^{\circ} \mathrm{C}$ until reaching the exponential growth phase (12h). After this period, the cellular density of the cultures was adjusted in a sterile $0.85 \%$ saline solution in order to obtain a turbidity comparable to tube 0.5 on the McFarland scale (Biomerieux Inc.), resulting in a microbial suspension containing approximately $1.5 \times 10^{8} \mathrm{CFU} / \mathrm{mL}$.

The agar diffusion method was used to evaluate antimicrobial activity, as described by standard M2-A8 of the Clinical and Laboratory Standards Institute - CLSI/ NCCLS (AGÊNCIA NACIONAL DE VIGILÂNCIA SANITÁRIA, 2003). Microbial Suspensions were seeded onto the surface of Mueller-Hinton agar (Difco). Wells with an internal diameter of $5 \mathrm{~mm}$ were made with a sterile punch, to which was added $25 \mu \mathrm{l}$ of the EO of L. Alba in binary 
concentrations ranging from 375 to $2.93 \mathrm{mg} / \mathrm{mL}$, prepared in Tween 80 1\%. The inoculated dishes were kept at room temperature for 30 minutes to allow diffusion of the $\mathrm{EO}$ and then incubated at $35{ }^{\circ} \mathrm{C}$ for $18 \mathrm{~h}$. The antimicrobial activity was evaluated by measuring the diameters of the growthinhibition halos around the wells. Halos with diameters equal to or greater than $7 \mathrm{~mm}$ were considered indicative of bacterial sensitivity to the EO. Sterile solutions of Tween 80 (VETEC) 1\% and amikacin (Sigma-Aldrich Co., St. Louis, MO, USA) $1.2 \mathrm{mg} / \mathrm{mL}$, were used respectively as negative and positive controls in the experiment. All the tests were carried out in duplicate.

The meteorological data of temperature, sunlight, relative humidity and rainfall were obtained from the records of the monitoring division of the Ceará Foundation for Meteorology (FUNCEME - DIMON). The data were tabulated and used for purposes of comparison with the quantitative and qualitative changes observed in the antimicrobial activity of the EO of L. alba.

\section{RESULTS AND DISCUSSION}

The EO of L. alba demonstrated antimicrobial activity against all of the tested microbial species at all times of the year (Table 1). The oil showed greater effectiveness against the Gram positive species tested. Among these, $S$. aureus was the most sensitive to the presence of the oil. A large influence on the antimicrobial efficiency of the EO, which varied for each microbial species evaluated, was seen for the various collection times. The EO obtained from December to February had the best response against the species $S$. aureus (5.9 mg/ml). Against L. Monocytogenes, the oil was more effective from June to August $(11.7 \mathrm{mg} / \mathrm{ml})$, while for L. Innocua, the EO showed a similar response for three periods of the year $(23.4 \mathrm{mg} / \mathrm{mL})$, differing only from March to May $(46.9 \mathrm{mg} / \mathrm{mL})$.

Comparison of the results presented in Table 1 with the meteorological data for the year 2010 (Table 2) makes it possible to verify that characteristics, typical of the period from December to February in the city of Paraipaba, Ceará (high temperatures, long periods of sunshine and low index rainfall), enhanced the action of the oil against $S$. Aureus, a microbial species which produces different enterotoxins and is frequently associated with food poisoning in humans from the consumption of contaminated food. From June to August, on the other hand, conditions favoured the action of the oil against L. monocytogenes and L. innocua.

According to Morais (2009), the chemical composition and content of the essential oil may undergo changes during the seasons of the year. As temperature and luminosity play important roles in photosynthesis, they influence the vegetative physiological process and, as a consequence, interfere with the content and composition of the EOs in the producing plants (SOUZA et al., 2008). Research evaluating the effect of seasonality associated with the time of harvesting on the production of biomass in L. alba, highlighted that the highest yields were obtained from collections made in the spring and summer, with the lowest obtained from that made in the winter (CASTRO, 2001).

The composition of the EO of L. Alba, previously reported by Corrêa (1992) and Matos et al. (1996), presents qualitative and quantitative variations, leading to the division of the plant into three chemotypes (I, II and III). Each chemotype demonstrates distinct morphological and pharmacological activities according to its major components, citral, carvone and linalool respectively. For Tavares et al. (2005) the phenological cycle and climatic conditions are factors that exert a strong influence on the composition and content of the EO of $L$. alba. These facts were also noted by Barros, Zambarda and Heinzmann (2009), who observed differences in both the oil yield and the biosynthesis of the structures of the two major classes of terpene (monoterpenes and sesquiterpenes) present in the EO of this species. The results presented in this study corroborate these reports, showing different levels of effectiveness for the EO of $L$. alba against different microorganisms, depending on the collection period. Such evidence suggests that seasonality is also

Table 1 - Antimicrobial activity of the essential oil of $L$. alba due to seasonality

\begin{tabular}{lcccccccc}
\hline \multirow{2}{*}{ Microrganism } & \multicolumn{2}{c}{ Dec - Feb } & \multicolumn{2}{c}{ Mar - May } & \multicolumn{2}{c}{ Jun -Aug } & \multicolumn{2}{c}{ Sep - Nov } \\
\cline { 2 - 8 } & Diameter IH $(\mathrm{mm})$ & $\mathrm{mg} / \mathrm{mL}$ & Diameter IH $(\mathrm{mm})$ & $\mathrm{mg} / \mathrm{mL}$ & Diameter IH $(\mathrm{mm})$ & $\mathrm{mg} / \mathrm{mL}$ & Diameter IH $(\mathrm{mm})$ & $\mathrm{mg} / \mathrm{mL}$ \\
\hline S. aureus & $8.0 \pm 2.8$ & 5.9 & $15.5 \pm 0.7$ & 23.4 & $8.5 \pm 0.7$ & 11.7 & $9.0 \pm 2.8$ & 11.7 \\
L. monocytogenes & $10.0 \pm 0.0$ & 23.4 & $9.0 \pm 1.4$ & 46.9 & $8.5 \pm 0.7$ & 11.7 & $11.5 \pm 0.7$ & 23.4 \\
L. innocua & $9.5 \pm 0.7$ & 23.4 & $10.5 \pm 0.7$ & 46.9 & $10.5 \pm 0.7$ & 23.4 & $8.5 \pm 2.1$ & 23.4 \\
E. coli & $7.5 \pm 2.1$ & 93.8 & $10.5 \pm 0.7$ & 187.5 & $\mathrm{NT}$ & $\mathrm{NT}$ & $10.0 \pm 0.0$ & 187.5 \\
P. aeruginosa & $8.0 \pm 2.8$ & 187.5 & $8.0 \pm 0.0$ & 187.5 & $7.5 \pm 0.7$ & 93.8 & $11.0 \pm 1.4$ & 187.5 \\
S. choleraesuis & $9.5 \pm 0.7$ & 93.8 & $9.0 \pm 0.0$ & 375 & $8.0 \pm 0.0$ & 187.5 & $8.0 \pm 0.0$ & 187.5 \\
\hline
\end{tabular}

IH: inhibition halo; NT: not tested 
Table 2 - Meteorological data for the four seasons of 2010 in Paraipaba, Ceará

\begin{tabular}{lcccc}
\hline \multicolumn{1}{c}{ Average } & Dec - Feb & Mar - May & Jun - Aug & Sep - Nov \\
\hline Temperature $\left({ }^{\circ} \mathrm{C}\right)$ & 27.8 & 26.9 & 25.6 & 27.4 \\
Total sunlight $(\mathrm{h})$ & 430.9 & 533.4 & 384.3 & 552.2 \\
Relative humidity (\%) & 72 & 78.7 & 76.8 & 67.7 \\
Accumulated rainfall (mm) & 32.7 & 78.7 & 22.0 & 71.0 \\
Days with rain & 9 & 15 & 1 & 1.3 \\
\hline
\end{tabular}

an influencing factor in the antimicrobial effectiveness of the EO of this plant species.

\section{CONCLUSIONS}

1. The essential oil from the leaves of $L$. alba demonstrates antimicrobial activity against all the bacterial species tested;

2. The seasonality of the constituents of the oil influences this antimicrobial activity. The greatest effectiveness was seen in the oil obtained from December to February, against the species $S$. aureus.

\section{REFERENCES}

ADÁMEZ, J. D. et al. In vitro estimation of the antibacterial activity and antioxidant capacity of aqueous extracts from grape-seeds (Vitis vinifera L.) Food Control, v. 24, n. 1/2, p. 136-141, 2012.

AGUIAR, J. S. et al. Atividade antimicrobiana de Lippia alba (Mill.) N. E. Brown (Verbenaceae). Revista Brasileira de Farmacognosia, v. 18, n. 3, p. 436-440, 2008.

AGÊNCIA NACIONAL DE VIGILÂNCIA SANITÁRIA. Padronização dos testes de sensibilidade a antimicrobianos por disco-difusão: norma aprovada. 8. ed. 2003. (NCCLS. Document, M2-A8, v. 23, n. 1). Disponível em: <http://www. anvisa.gov.br/ rebla/reblas_public_disc-_difusao.pdf >. Acesso em: 26 Jan. 2012.

BAKKALI, F. et al. Biological effects of essential oils - a review. Food and Chemical Toxicology, v. 46, n. 2, p. 446-475, 2008.

BARROS, F. M. C.; ZAMBARDA, E. O.; HEINZMANN, B. M. Variabilidade sazonal e biossíntese de terpenóides presentes no óleo essencial de Lippia alba (Mill.) N. E. Brown (Verbenaceae). Química Nova, v. 32, n. 4, p. 861-867, 2009.

CASTRO, D. M. Efeito da variação sazonal, colheita selecionada e temperaturas de secagem sobre a produção de biomassa, rendimento e composição de óleos essenciais de folhas de Lippia alba (Mill.)N. E. Br ex Britt. \& Wilson (Verbenaceae). 2001. 132 f. Tese (Doutorado em Horticultura). - Universidade Estadual Paulista, Botucatu, 2001.
CORRÊA C. B. V. Contribuição ao estudo de Lippia alba (Mill.) N. E. Br. ex Britt \& Wilson - erva-cidreira. Revista Brasileira de Farmacognosia, v. 73, n. 3, p. 57-64, 1992.

CRAVEIRO A. A.; MATOS, F. J.; ALENCAR, J. W. A simple and inexpensive steam generator for essential oils extraction. Journal of Chemical Education, v. 53, n 10, p. 652, 1976.

GAO, C. et al. Essential oil composition and antimicrobial activity of Sphallerocarpus gracilis seeds against selected food-related bactéria. Food Control, v. 22, n. 3/4, p. 517522, 2011.

KOTZEKIDOU, P.; GIANNAKIDIS, P.; BOULAMATSIS, A. Antimicrobial activity of some plant extracts and essential oils against foodborne pathogens in vitro and on the fate of inoculated pathogens in chocolate. LWT, v. 41, n. 1, p. 119127, 2008.

MATOS, F. J. A. et al. Essential oil composition of two chemotypes of Lippia alba grown in northeast Brazil. Journal of Essential Oil Research, v. 8, n. 6, p. 695-698, 1996.

MATOS, F. J. A. Farmácias vivas. Fortaleza: EUFC, 1998.

MORAIS, L. A. S. Influência dos fatores abióticos na composição química dos óleos essenciais. Horticultura Brasileira, v. 27, n. 2, p. 4050-4063, 2009.

NGUEFACKA, J. et al. Synergistic action between fractions of essential oils from Cymbopogon citratus, Ocimum gratissimum and Thymus vulgaris against Penicillium expansum. Food Control, v. 23, n. 2, p. 377-383, 2012.

SANDRI, I. G. et al. Antimicrobial activity of the essential oils of Brazilian species of the genus Cunila against foodborne pathogens and spoiling bactéria. Food Chemistry, v. 103, n. 3, p. 823-828, 2007.

SCHELZ, Z.; MOLNAR, J.; HOHMANN, J. Antimicrobial and antiplasmid activities of essential oils. Fitoterapia, v. 77, n. 4, p. 279-285, 2006.

SMITH-PALMER, A.; STEWART, J.; FYFE, L. The potential application of plant essential oils as natural food preservatives in soft cheese. Food Microbiology, v. 18, n. 4, p. 463-470, 2001.

SOUZA, J. R. P. et al. Desenvolvimento da espinheira-santa sob diferentes intensidades luminosas e níveis de poda. Horticultura Brasileira, v. 26, n. 1, p. 40-44, 2008. 
TAVARES, E. S. et al. Análise do óleo essencial de folhas de três quimiotipos de Lippia alba (Mill.) N. E. Br. (Verbenaceae) cultivados em condições semelhantes. Revista Brasileira de Farmacognosia, v. 15, n. 1, p. 1-5, 2005.

TATSADJIEU, N. L. et al. Investigations on the essential oil of Lippia rugosa from Cameroon for its potential use as antifungal agent against Aspergillus flavus Link ex. Fries. Food Control, v. 20, n. 2, p. 161-166, 2009.
TEPE, B. et al. Antimicrobial and antioxidant activities of the essential oils and various extracts of Salvia tomentosa Miller (Lamiaceae). Food Chemistry, v. 90, n. 3, p. 333340, 2005 .

VIUDA-MARTOS, M., et al. Antifungal activities of thyme, clove and orégano essential oils. Journal of Food Safety, v. 27, n. 1, p. 91-101, 2007. 